\title{
Chapter 7 \\ Rights-Based Freshwater Governance for the Twenty-First Century: Beyond an Exclusionary Focus on Domestic Water Uses
}

\author{
Barbara Van Koppen, Anne Hellum, Lyla Mehta, Bill Derman, \\ and Barbara Schreiner
}

\begin{abstract}
The UN recognition of a human right to water for drinking, personal and other domestic uses and sanitation in 2010 was a political breakthrough in states' commitments to adopt a human rights framework in carrying out part of their mandate. This chapter explores other domains of freshwater governance in which human rights frameworks provide a robust and widely accepted set of normative values to such governance. The basis is General Comment No. 15 of the Committee on Economic, Social and Cultural Rights in 2002, which states that water is needed to realise a range of indivisible human rights to non-starvation, food, health, work and an adequate standard of living and also procedural rights to participation and information in water interventions. On that basis, the chapter explores concrete implications of the Comment for states' broader infrastructure-based water services
\end{abstract}

\footnotetext{
B. Van Koppen $(\square)$

International Water Management Institute, Southern Africa Regional Programme,

Private Bag X813, Silverton 0127, South Africa

e-mail: b.vankoppen@cgiar.org
}

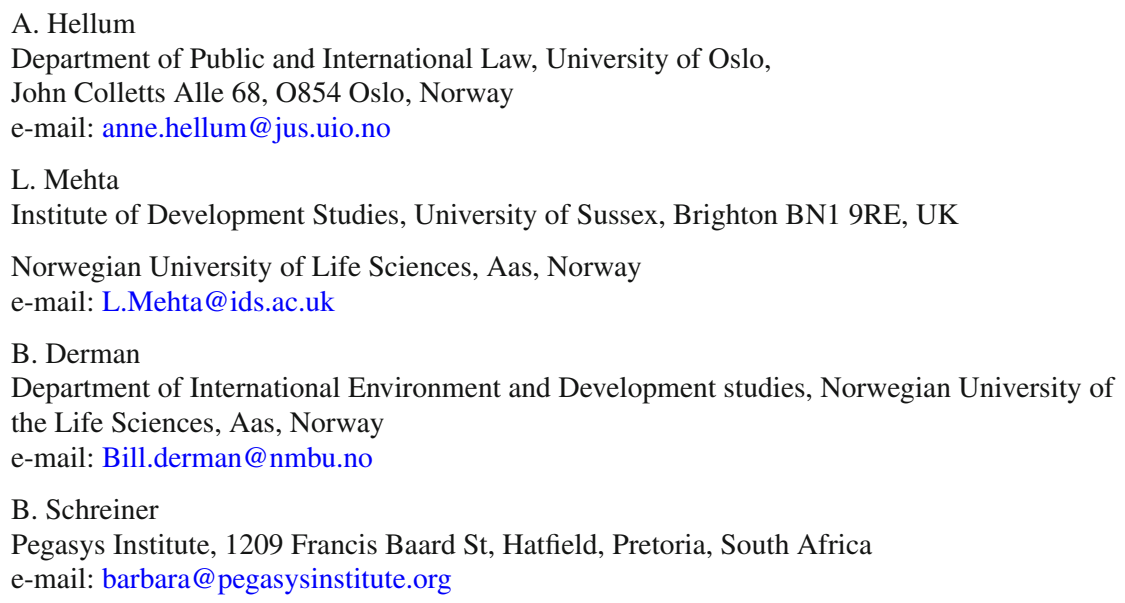

A. Hellum

Department of Public and International Law, University of Oslo, John Colletts Alle 68, O854 Oslo, Norway

e-mail: anne.hellum@jus.uio.no

L. Mehta

Institute of Development Studies, University of Sussex, Brighton BN1 9RE, UK

Norwegian University of Life Sciences, Aas, Norway

e-mail: L.Mehta@ids.ac.uk

B. Derman

Department of International Environment and Development studies, Norwegian University of the Life Sciences, Aas, Norway

e-mail: Bill.derman@nmbu.no

B. Schreiner

Pegasys Institute, 1209 Francis Baard St, Hatfield, Pretoria, South Africa

e-mail: barbara@pegasysinstitute.org 
implied in the recognised need to access to infrastructure, rights to non-discrimination in public service delivery and respect of people's own prioritisation. This implies a right to water for livelihoods with core minimum service levels for water to homesteads that meet both domestic and small-scale productive uses, so at least 50-100 l per capita per day. Turning to the state's mandates and authority in allocating water resources, the chapter identifies three forms of unfair treatment of smallscale users in current licence systems. As illustrated by the case of South Africa, the legal tool of "Priority General Authorisations" is proposed. This prioritises water allocation to small-scale water users while targeting and enforcing regulatory licences to the few high-impact users.

Keywords Human rights - Freshwater governance - Socioeconomic rights • Multiple-use water services $\bullet$ Water allocation $\bullet$ Licence systems

\subsection{Introduction}

In 2010, the United Nations (UN) General Assembly and the UN Human Rights Council adopted two resolutions that affirmed the recognition of the right to water for drinking, personal and other domestic uses and sanitation as a justiciable and enforceable human right derived from the right to an adequate standard of living (A/ RES/64/292 in UN 2010a; and A/HRC/RES/15/9 in UN 2010b). The far-reaching, legally binding implication was that it obliged states as duty bearers to ensure that every citizen has affordable access to water infrastructure services for drinking, personal and other domestic uses and sanitation. This political commitment was a breakthrough in linking water development and management with international human rights frameworks and national rights-based constitutions. The narrow focus on safe drinking water, personal and other domestic uses and sanitation represents a political priority that does not fully correspond to the right to an adequate living standard, which includes water as a part of the right to food. Some governments, for example, of South Africa and India, have enacted rights-based water laws that make prioritisation of domestic water uses and sanitation mandatory. Many national and international human rights institutions; public water, sanitation and hygiene organisations; and civil society organisations also prioritise its realisation (UNICEF and WHO 2015; WaterLex 2014).

However, this prioritisation does not exclude similar rights-based prioritisation in other domains of water development and management, on the contrary. The premise of this chapter is that international human rights instruments and constitutional rights are a highly appropriate, if not the only, normative yardstick for states in the twenty-first century to fulfil their duty and authority in freshwater governance in the broadest sense. This premise is not unique to the water sector. Human rights have been mainstreamed in the UN's development planning since 1997. In 2003, the UN produced a statement of Common Understanding on Human Rights-Based 
Approaches to Development Cooperation, and in 2009, the 19 organisations of the United Nations Development Group established the Human Rights Mainstreaming Mechanism (Baillat et al. 2013). Human rights also inspire citizens and states, as in Tanzania, Kenya, South Africa and Zimbabwe, to adopt new rights-based constitutions to shed the legal legacy of their colonial predecessors. As also reflected in the UN Sustainable Development Goals (SDGs), a global consensus is emerging on human values embodied in human and constitutional rights. This is undoubtedly the world's most influential normative value system and yardstick to steer global and national state interventions. These trends also provide fertile ground for rightsbased freshwater governance in the broad sense, including, but not limited to, a priority for water for drinking, personal and other domestic uses and sanitation alone.

In the water sector, a growing number of human rights institutions, civil society organisations and researchers have conceptualised rights-based freshwater governance and have invoked human rights frameworks in action and litigation. For example, a call for wastewater management supported the realisation of the right to sanitation. Various national and global human rights institutions, especially in Latin America, exposed major water pollution and damage by mines and exclusion from any voluntary, informed and prior consent as violation of the human right to a clean environment (WaterLex 2014). In other cases, rights to a clean environment are invoked to justify a quantitative reservation of "environmental flows". New issues have been raised pertaining to the duty of the state to ensure flood protection and prevent soil erosion (WaterLex 2014).

The past two decades have also seen a strong global move towards participation, transparency, accountability and access to information or "free, prior and informed consent". In some cases of large-scale investments in dams, for example, in Latin America, human rights to participation are invoked. However, others, such as the global Water Integrity Network, aim at transparency, accountability and participation in the water sector and combating corruption as values on their own, and reference to human rights is rare. A case that is raised as a human rights issue with far-reaching implications regards the nature of private water services providers' obligations relating to disclosure of environmental information (WaterLex 2014).

Duties of the state to realise constitutional rights and international human rights that it ratified also hold for two other core mandates of the state in freshwater governance. One is public infrastructure-based service provision for productive water uses, including agriculture, mining and industries. Water volumes used for productive purposes are much higher than for domestic uses; the latter represent at the most two to three percent of total water volumes used. The state is also the primary regulatory authority, not only with responsibilities to safeguard water quality as mentioned, but also responsible for the allocation of water quantities, often as the statutory custodian of the nation's water resources.

The importance of rights-based approaches in these two core tasks of states is increasingly recognised. The Water Governance Facility of the United Nations Development Programme at Stockholm International Water Institute (WGF 2012) emphasised precisely these domains: "Human Rights Based Approaches can be 
very useful to advance equity aspects of distribution of water rights and nondiscrimination of water resources management and allocation" (WGF 2012: 5). "The international human rights framework can help to set development priorities and provide a way to address conflicting rights and interests that is transparent and emphasises redress when rights are violated" (WGF 2012: 12). Rights-based approaches fill a major gap in the dominant discourse of Integrated Water Resource Management (IWRM), as "In practice IWRM has to a large degree neglected to directly address social equity issues and Human Rights Based Approaches can be seen as a methodology to strengthen such work" (WGF 2012: 13).

The High Level Panel of Experts on Food Security and Nutrition in their report on Water for Food Security and Nutrition examined the interlinkages between food security, water and nutrition in relation to the right to food and the current right to water for personal and domestic uses. One of the key recommendations is "Promoting a rights-based approach to water for food security and nutrition" (HLPE 2015: 108).

Scholars started exploring concrete implications of rights-based approaches for women, the poor and other marginalised groups. Hellum et al. (2015) invoked the right to non-discrimination in the Convention of the Elimination of All Forms of Discrimination against Women. Recognising the indivisibility of rights and the importance of both domestic and productive uses of water for multifaceted wellbeing, they made the case for a gender-equal right to water for livelihoods (Hellum et al. 2015).

In the remainder of this chapter, we will further examine concrete implications of closing the current gap between the state as duty bearer of human rights and the state as infrastructure-based water provider for both domestic and productive uses and as regulator in allocating water resources. The focus is on the most marginalised women and men in low- and middle-income countries, whose human rights to water are most severely violated. In the following, we first go back to the first milestone in connecting human rights and water management. This is the legal opinion on the human right to water by the Committee on Economic, Social and Cultural Rights (CESCR), in its General Comment No. 15 of 2002 (UN CESCR 2003). This Comment prioritised water for drinking and other domestic uses and underpinned the Resolutions in 2010. However, as we will see in the next section, this Comment also clearly identified prioritisation in other dimensions of freshwater governance, in particular in infrastructure development and water allocation.

Section 7.3 discusses rights-based approaches for the core function of the state of promoting infrastructure development, partly by own public investments in infrastructure and partly by promoting others to invest. Section 7.4 examines rightsbased state regulation in the quantitative allocation of water resources, as illustrated by experiences in South Africa. Section 7.5 draws conclusions. 


\title{
7.2 Broader Prioritisation in CESCR General Comment No. 15
}

Unlike the right to food, the right to water was not explicitly acknowledged in the 1948 Universal Declaration of Human Rights. Water was only indirectly referred to as derived from the right to life and dignity. Explicit but very brief references to a right to water were made in the Convention on the Elimination of All Forms of Discrimination against Women (UN 1979) and the Convention on the Rights of the Child (UN 1990). The process of recognition of the right to water thus evolved much later than the right to food (Mehta 2014; Hellum et al. 2015).

On November 27, 2002, the United Nations Committee on Economic, Social and Cultural Rights adopted the General Comment No. 15 on the Right to Water, elaborating the norms and definitions of the human right to water. ${ }^{1}$ The Committee articulated both substantive and procedural aspects of a human right to water (UN CESCR 2003). It highlighted the many ways in which a right to water is derived from and contributes to realising other socioeconomic rights, referring to the Vienna Declaration (UN 1993) that states: "All human rights are universal, indivisible and interdependent and interrelated. The international community must treat human rights globally in a fair and equal manner, on the same footing, and with the same emphasis".

While emphasising a priority for water provision for personal and domestic uses, the Comment recognises that priorities also and simultaneously include water to prevent starvation and meet "core obligations" in general. Sanitation is also mentioned:

Water is required for a range of different purposes, besides personal and domestic uses, to realize many of the Covenant rights. For instance, water is necessary to produce food (right to adequate food) and ensure environmental hygiene (right to health). Water is essential for securing livelihoods (right to gain a living by work) and enjoying certain cultural practices (right to take part in cultural life). Nevertheless, priority in the allocation of water must be given to the right to water for personal and domestic uses. Priority should also be given to the water resources required to prevent starvation and disease, as well as water required to meet the core obligations of each of the Covenant rights. (General Comment No. 15 para 6)

General Comment No. 15 further explicitly refers to farming and livelihoods and the need for infrastructure to realise access to water:

\begin{abstract}
People should not be deprived of their means of subsistence. States should ensure adequate access to water for subsistence farming and for securing the livelihoods of indigenous peoples. This also entails that disadvantaged and marginalized farmers, including women farmers, have equitable access to water and water management systems, including sustainable rain harvesting and irrigation technology. (General Comment No. 15 para 7)
\end{abstract}

\footnotetext{
${ }^{1}$ General Comment No. 15, The right to water (arts. 11 and 12 of the International Covenant on Economic, Social and Cultural Rights - ICESCR), U.N. Doc. E/C.12/2002/11 (Twenty-ninth session, 2002). The Committee on Economic, Social and Cultural Rights (CESCR) monitors the implementation of the International Covenant on Social, Economic and Cultural Rights (UN 1966). General comments are interpretations of the contents of rights included in the ICESCR by the Committee. The Committee stressed the State's legal responsibility in fulfilling the right and defined water as a social and cultural good and not solely an economic commodity.
} 
Referring to the general right to non-discrimination, "the right of access to water and water facilities and services should be ensured on a non-discriminatory basis, especially for disadvantaged or marginalized groups" (General Comment No. 15 para 8).

The Comment also includes procedural rights:

The right of individuals and groups to participate in decision-making processes that may affect their exercise of the right to water must be an integral part of any policy, programme or strategy concerning water. Individuals and groups should be given full and equal access to information concerning water, water services and the environment, held by public authorities or third parties. (General Comment No. 15 para 48)

Impacts from state and non-state actors' actions are included in these procedural rights:

Before any action that interferes with an individual's right to water is carried out by the State party, or by any other third party, the relevant authorities must ensure that such actions are performed in a manner warranted by law, compatible with the Covenant, and that comprises: (a) opportunity for genuine consultation with those affected; (b) timely and full disclosure of information on the proposed measures; (c) reasonable notice of proposed actions; (d) legal recourse and remedies for those affected; and (e) legal assistance for obtaining legal remedies. (General Comment No. 15 para 25)

As mentioned, the prioritisation for domestic water uses in General Comment No. 15 was the basis for the breakthrough in rights-based approaches to water development and management in 2010. In the next section, we explore the implications of General Comment No. 15 for prioritisation in infrastructure development for productive and multiple water uses.

\subsection{Rights-Based Water Services for Productive and Multiple Water Uses}

Infrastructure development is society's primary way to ensure that water of the right quality and quantity is available at the right time at the right site for human use or to protect against flooding and too much water. Storage infrastructure increases the quantities of water resources available for human use year-round, so as to "increase the pie" of available water. Water "infrastructure" is broad; it ranges from buckets or micro-basins to capture run-off for plant roots to large-scale dams. The state plays a crucial role in infrastructure development by investing in construction, operation and maintenance or by enabling and capacitating people to invest themselves in technologies for self-supply, for example, by training or supporting water technology supply chains and dissemination of, for example, affordable pumps and energy.

A human right to state-promoted infrastructure services for productive water uses to realise the right to non-starvation, food, work and an adequate standard of living can be derived from at least three aspects of General Comment No. 15. The 
first aspect is the Comment's acknowledgement that irrigation and water-harvesting technologies (or more broadly, agricultural water management technologies) are needed and, hence, that the state is a duty bearer in respecting, protecting and fulfilling this need, in the same way as the state already commits to the current human right to water for personal and domestic uses.

The second aspect, namely, the reference in the General Comment to equitable access and non-discrimination in state subsidies in public irrigation schemes and other projects, raises pertinent new questions about the beneficiaries of public investments in water infrastructure. The water, sanitation and hygiene subsector measures the performance of its services in terms of people reached with those services. In contrast, people are largely invisible in the productive water subsectors. For example, irrigation performance indicators are about sizes of irrigated land, kilometres of canals and perhaps performance and users' satisfaction about water service delivery, crop yields and potential aggregate incomes. Numbers of farmers, let alone their gender or class, are lacking in routine monitoring. At best, assumptions about beneficiaries can be made on the basis of the affordability of technology: bucket irrigation is likely to benefit the poorest.

More broadly as well, the terminologies for productive water uses are monolithic, abstract, aggregate "sectors", such as "the" irrigation, hydropower, mining or municipal water sectors. Major intra-sectoral differences between, for example, small-scale subsistence farmers and large-scale agribusiness are too often overlooked. Connecting two or three sectors into a "nexus" confirms this people-blind discourse. This persistent single-water use and sector-based discourse hides inequalities, depoliticises priority setting and is a strong obstacle for any people-centred approach, including human rights-based approaches. Benefits of irrigation schemes depend on irrigated area, so people with more land benefit more from "irrigation" investments. Or as illustrated in South Africa, it is true that the government is progressively working towards non-discrimination in access to public funding and payment for municipal and irrigation water services by those who can pay. However, a sector-based language continues to hide how the "haves" who benefitted from large public investments in sophisticated infrastructure by the apartheid state are still the main beneficiaries of state subsidies to operate and maintain these bulk water supplies. Insight into the distribution of benefits of public sector-based fund allocation and the grounds for this distribution is likely to reveal unfair discrimination.

Hidden in these sectors, poor women's and men's water needs for productive uses to meet the human right to food and an adequate standard of living and cultural uses and to prevent starvation are mostly ignored. Yet, without alternative livelihood strategies, poor people tend to have more diversified and climate-dependent livelihoods than anyone else and, hence, depend more than anyone else on secure access to water for a range of productive uses in livestock, cropping, horticulture, fisheries, tree growing, crafts and small-scale enterprise.

The third aspect of General Comment No. 15 that underpins a right to water infrastructure services for productive uses is the right to participation. In addition to ensuring participatory procedures, participation also concerns respecting, protecting and fulfilling poor people's own priorities for domestic and a range of productive 
uses. These priorities for multiple uses are overlooked in the single-use sectoral approaches of the compartmentalised water sector, in which infrastructure is designed for one single use, either irrigation, or domestic uses, or livestock. Such infrastructure designed by public planners for single uses is in reality and invariably turned into multipurpose infrastructure (Van Koppen et al. 2009, 2014a).

"Domestic" water supplies are used for a range of productive uses, which help meeting basic food supplies and income generation (Moriarty et al. 2004). For example, Hall et al. (2013) found that even at consumption levels of 201 per capita per day, half of the households used these quantities for domestic and productive uses. In mountainous areas with free gravity energy in Colombia, the proportion of households using pipes for multiple uses is $82-98 \%$ in three rural areas, but only just below $50 \%$ in two urban areas (Van Koppen et al. 2009). Pérez de Mendiguren Castresana (2004) found in a rural area in South Africa that the proportion of households using "domestic" supplies for productive uses was higher where the water supplies were more reliable. Similarly, irrigation schemes are used for multiple purposes as the rule, also by the landless and women who don't have access to irrigated land (Meinzen-Dick 1997; Renault et al. 2013). Infrastructure exclusively for irrigation is the exception, for example, as groundwater pumping in distant fields.

Instead of declaring such non-planned uses as "illegal" and trying to prevent these uses (typically in vain), these uses should be acknowledged as people's right to set their own priorities. Irrigation planners should certainly respect people's priority for domestic uses. In genuine participatory water services, people's multiple water needs and priorities should be the starting point of planning and providing water services. Since the early 2000s, this approach of so-called Multiple Use Water Services (MUS) has been field tested across the world and is now applied in 22 countries (see www.musgroup.net). Multipurpose infrastructure and locally driven combinations of multiple water sources also emerged spontaneously wherever the prioritisation of general development interventions was left to local players. This was the case in India's Mahatma Gandhi National Rural Employment Guarantee Scheme, which reaches 55 million people per year. This turned out to be the world's largest rural water supply programme (Verma et al. 2011). The development of multipurpose infrastructure, in which water is taken from multiple sources to meet multiple needs, is the way in which communities have been managing their water resources since time immemorial in a more cost-effective and environmentally friendly way than the public sector.

One concrete implication of these aspects of General Comment No. 15 for infrastructure-based services is a new definition of the substantive core minimum human right to infrastructure-based water services. Currently, service levels for water supplies delivered near or at homesteads are 20-50 l per capita per day, supposedly to meet personal and domestic needs (and sanitation) only. This should be raised to 50-100 1 per capita per day in order to also enable basic productive uses (Hall et al. 2013; Van Koppen et al. 2014a). Unlike irrigation development that tends to disproportionately favour those with more land, multiple-use water services to homesteads benefit everybody, including the land-poor and landless, childheaded households, the sick and disabled. Out of these quantities, three to five litres 
per capita per day should be safe for drinking and cooking, for example, through point-of-use water treatment as also recommended by health specialists. Insisting on the high drinking water quality standards for all other domestic water uses and productive water uses can be a wasteful expenditure.

\subsection{Rights-Based Water Allocation}

With increasing competition for water, the role of the state in water allocation becomes increasingly important as well. This is also the case in the widespread land acquisitions and grabs that are typically accompanied by water grabs. The Special Rapporteur on the right to food has, in recent years, frequently commented on their impact(s) on local people's food security (Franco et al. 2013). As a result of these challenges, there have been growing calls to elaborate a human rights perspective to land and to water that is more interconnected, more social justice oriented and more participatory and encompasses the use of water for production of food at the household level to meet the right to food (Franco et al. 2013).

The case of South Africa highlights the challenges and potential rights-based solutions at stake. South Africa articulated a progressive rights-based constitution under its post-1994 dispensation, committing to sufficient access to water and food for all (RSA 1996: section 27 (2)). It translated these rights into a rights-based Water Services Act (1997) prioritising access to water for domestic uses and sanitation for all. The South African Human Rights Commission proactively monitors the realisation of constitutional rights, including the right to water and sanitation (SAHRC 2014).

Moreover, the National Water Act (1998) (RSA 1998) also formally addresses the highly unequal distribution of water use as a result of the land and water grabs in the colonial era. Calculations show that $1.2 \%$ of the population uses $95 \%$ of the allocated water resources, leading to a Gini coefficient of 0.99 for rural areas (Cullis and Van Koppen 2008). The constitutional commitment to redress the inequities of the past is translated into the National Water Act as the legal possibility of a distributive water reform to reallocate water from the "haves" to the "have-nots". Under certain conditions those who have to give up a small share of their water allocations for that purpose are not compensated. The Act further enshrines legal instruments to allocate water resources, while also redressing inequities of the past. The periodic National Water Resource Strategy sets priorities. The administrative system to implement water allocation is the licence (or permit) system. The latter system is widely applied elsewhere in the world as well (Van Koppen et al. 2014b). The issuing and monitoring of licences are the government's main tool to regulate water users, for example, by rejecting an application for a licence altogether in overallocated areas or by setting caps on volumes used and reducing the period of a licence. Waste discharge conditions (the polluter pays) and payment for water resource management tasks (the user pays) are other conditions tied to licences. Obviously, such regulation to safeguard sufficient availability of water of the right 
quality is especially important for the marginalised, who are often hit hardest by others' overuse and pollution. So licences can be vital tools to implement rightsbased water allocation. However, as further discussed below, what is often ignored is that the licence system is also the only way to obtain formal entitlements to water.

In 2008, this commitment to redress the inequities of the past was operationalised in a Water Allocation Reform. This sets as targets that $60 \%$ of allocable water should be in black hands ("black" meaning Africans, Coloureds and Indians) by 2020, equally divided among women and men (DWAF 2008). Moreover, the National Water Resource Strategy (2nd volume) (DWA 2013a) follows the main principle of General Comment No. 15 in prioritising water uses for poverty eradication and redress of inequities of the past as the third highest priority. The first priority is for the Reserve, which consists of a Human Basic Needs Reserve (which is currently set at 251 per capita per day and amounts to just one percent of the mean annual run-off) and an Ecological Reserve (which is set at considerably higher volumes of about one fifth of the mean annual run-off). The second priority is for international obligations. Significantly, water use for poverty eradication and redress of inequities of the past has a higher priority than so-called strategic uses, which is mainly electricity generation and, lastly, water for general economic purposes that require licences.

In spite of these progressive policies and regulations, the disappointing reality is that the distribution of all new water uses that were taken up after the promulgation of the National Water Act (1998) has remained as skewed as before. Out of the 4284 water-use licences for new water uptake issued between 1998 and 2012, only 1518 were for black individuals. Significantly, the total volumes allocated to them were very low: just $1.6 \%$ of total water allocated through all licences (DWA 2013b). The percentage of women licence holders is probably less than $10 \%$ (Anderson, personal communication).

While this perpetuation of inequalities is largely the result of a continued lack of access to water infrastructure and skewed land tenure, the policies, regulations and the Water Allocation Reform targets fail to be operationalised. Even worse, the main water allocation tool to operationalise redress, the licence system, is designed in such a way that it treats black women and men, the majority of whom are smalland microscale water users, unfairly (as in many licence systems elsewhere). There are three grounds why this treatment is unfair.

First, while introducing the licence system, the National Water Act (1998) consolidated the racial discrimination of black people entrenched in past water rights regimes. The Act recognises Existing Lawful Uses that were lawful under the water laws preceding 1998 as continuing to be lawful until those rights are converted into licences (under a specific process of compulsory licensing in specific geographic areas with one or more water resources). Those former laws were a patchwork of legal arrangements, including riparian rights, access to normal and surplus flows, private groundwater rights, irrigation schedules determined by the irrigation boards, permits for commercial afforestation, permits in area-specific Government Water Control Areas (in both the white Republic of South Africa and former homelands) and very weak rights for Africans in former homelands, on white-owned farms or black townships. The homelands were declared as state land, so the water resources 
were also owned by the colonial state. Formally, this right could be transferred to inhabitants of the homelands. However, in practice, this hardly ever happened. This was "justified" by referring to the bureaucracy: "Sometimes the problem was to determine which official of the State had to grant the necessary permission" (Thompson et al. 2001). In reality, in homelands and on white-owned farms and peri-urban settlements, living customary water rights regimes coexisted with the formal legislative regime. The recognition of the "Existing Lawful Uses" not only implied the acceptance of the highly skewed distribution of water uses but also consolidated the much weaker legal status of customary living laws in the former homelands, on large-scale farms and peri-urban settings. Where white men can, and do, refer to well-defined pre-1998 rights, black people cannot, not even to the much smaller quantities used.

The second ground of unfair treatment of small-scale users regards the obligatory application for licences for the uptake of new water or the area-wide application of licensing by every water user under compulsory licensing. In this process, small-scale water users, the large majority of whom are black people, face disproportionate administrative costs for relatively small volumes of water. Even though procedures for small-scale users are less complex than for high-impact users, the efforts remain disproportionate. Moreover, through no fault of their own, the state is not even able to allocate its scarce human resources to reach out to all small-scale water users who typically live in remote areas with fewer transport and administrative facilities. Women are even more discriminated because licences are typically allocated in the name of the household head, which is assumed to be a man and only by default a woman.

Micro-users are exempted from the obligation to apply for a licence. This is a third form of unfair treatment, because the legal status of exempted microscale water uses is second-class, as confirmed by the FAO (2004):

The problem is that a person who seeks to benefit from such an entitlement cannot lawfully prevent anyone else from also using the resource even if that use affects his own prior use/ entitlement. Indeed the question arises as to whether or not they really amount to legal rights at all. (FAO 2004)

In line with both General Comment No. 15 and the National Water Resource Strategy (2nd volume), this unfair treatment can be ended by rights-based water allocation, which legally prioritises water uses that meet the constitution's socioeconomic rights to access to sufficient water and food, especially by (indigenous) black people (Van Koppen and Schreiner 2015). In South Africa, this can be operationalised through the Act's legal tool of so-called General Authorisations. These are exemptions to the obligation to apply for a licence for small-scale uses for specific groups or water sources, just above the exempted microscale uses (Anderson et al. 2007). By vesting a priority in such General Authorisation, the second-class legal status of exemptions shifts, in principle, to premium-class legal entitlement status in line with the high priority in the National Water Resource Strategy (2nd volume). The threshold above which water users need to apply for a licence and below which they are exempted could be set by realistically assessing the state's 
logistic capacity to issue and monitor licences of many small-scale users who, together, still hardly use any significant water volumes and the handful of highimpact users, such as mines and large-scale farmers. State capacity is low; till today, many of the high-impact users still get away without any licence, so without any state regulation of their water use and waste discharge. As custodian of the nation's water resources, the minister can issue such priority general authorisation with the stroke of a pen. However, this option is still being debated, even though such rightsbased priority entitlement to water does not oblige the state in any way to also provide the infrastructure.

\subsection{Conclusion}

In this chapter, we discussed how international human rights instruments in general and the CESCR General Comment No. 15 on the human right to water in particular provide a robust normative system that is well able to address end goals of human well-being across the key mandates of the water sector, namely, infrastructure development and water resource allocation. Moreover, the recognition of the indivisibility and interdependency of human rights applies exceptionally well to water resources. Water is key to many dimensions of human well-being and ill-being. Secure access to water is especially important for the agrarian livelihoods of the rural and peri-urban poor.

While the recognition of a justiciable and enforceable right to water for drinking, personal and other domestic uses and sanitation has been an important milestone in closing the disconnection between the state as duty bearer for human rights and the state as investor in water infrastructure and regulator, we argued that this has only been a very partial interpretation of the underpinning General Comment No. 15 of the Committee on Economic, Social and Cultural Rights. The same Comment also indicates priorities in other freshwater governance domains to realise the substantive rights to livelihoods, food, health and an adequate standard of living. This has concrete implications for the state's infrastructure-based water services. Poor people's productive water needs should be fully recognised and met in a nondiscriminatory manner. The definition of a core minimum should not be assumed to be for domestic uses only, but should include water for small-scale productive uses at and around homesteads as well. This priority for multiple basic uses is already widespread practice, but often still seen as "illegal" by sectoral professionals who design single-use infrastructure. An inclusive people-driven planning process for infrastructure services will spontaneously identify such multiple priorities.

A concrete implication of a rights-based approach to the state's authority and responsibility in water allocation is that water should be available for such basic uses to meet the right to food, health and an adequate standard of living. Priorities in allocation should safeguard such minimum volumes. This should not only be defined in policies and regulations, but also operationalised in the legal instruments to allocate water. Licence systems in particular should be redesigned to prioritise 
such uses, while targeting regulation and prioritising the state's resources to enforce compliance to the large-scale high-impact users who overuse and pollute water most severely.

The identification of these further implications of General Comment No. 15 underlines the chapter's premise that human rights frameworks provide the indispensable normative framework for twenty-first-century freshwater governance.

\section{References}

Anderson, A., Quibell, G., Cullis, J., \& Ncapayi, N. (2007). General authorisations as a tool to promote water allocation reform in South Africa. Law, Environment and Development Journal, $3(2), 164-178$.

Baillat, A., Schmitz, T., \& Szabó, M. (2013). Towards a human rights based water governance: Challenges for the post 2015 thematic consultations on water. WaterLex, Geneva, Switzerland. http://www.waterlex.org/new/wp

Cullis, J., \& Van Koppen, B. (2008). Applying the Gini coefficient to measure the distribution of water use and benefits of water use in South Africa's provinces (Unpublished report). Department of Water Affairs and Forestry and International Water Management Institute, Pretoria, South Africa.

Department of Water Affairs (DWA), Republic of South Africa. (2013a). National Water Resource Strategy (2nd edn, Water for an Equitable and Sustainable Future). Pretoria: Department of Water Affairs.

Department of Water Affairs (DWA), Republic of South Africa. (2013b). Water allocation reform. Portfolio Committee on Water and Environmental Affairs. PowerPoint presentation, 16 April 2013. http://d2zmx6mlqh7g3a.cloudfront.net/cdn/farfuture/b24vv0q7YzDjaLQee34wk_VAU_ uXpX1_3cq8Lf-w

Department of Water Affairs and Forestry, Republic of South Africa. (2008). Water allocation reform strategy. Pretoria: Chief Directorate Water Use, Department of Water Affairs and Forestry.

FAO. (2004). Land and water - The rights interface (FAO Legislative Study 84). Rome: Food and Agricultural Organization of the United Nations.

Franco, J., Mehta, L., \& Veldwisch, G. J. (2013). The global politics of water grabbing. Third World Quarterly, 34(9), 1651-1675.

Hall, R., Van Koppen, B., \& Houweling, E. (2013). The human right to safe and clean drinking water: A necessary condition for, and limitation on, development in rural and peri-urban communities. Science and Engineering Ethics, 20(4), 849-868. doi:10.1007/s11948-013-9499-3.

Hellum, A., Ikdahl, I., \& Kameri-Mbote, P. (2015). Against the current: Engendering the human right to water and sanitation. In A. Hellum, M. Kameri, \& B. Van Koppen (Eds.), Water is life: Women's human rights in national and local water governance in Southern and Eastern Africa. Harare: Weaver Press.

High Level Panel of Experts. (2015). Water for food security and nutrition. A report by the High Level Panel of Experts on Food Security and Nutrition of the Committee on World Food Security, HLPE, Rome, Italy.

Mehta, L. (2014). Water and human development. World Development, 59, 59-69.

Meinzen-Dick, R. (1997). Valuing the multiple uses of water. In M. Kay, Y. Franks, \& L. Smith (Eds.), Water: Economics, management and demand (pp. 50-58). London: E\&FN Spon.

Moriarty, P., Butterworth, J., \& Van Koppen, B. (Eds.). (2004). Beyond domestic: Case studies on poverty and productive uses of water at the household level (IRC technical papers series 41). Delft: IRC/NRI/IWMI. 
Pérez de Mendiguren Castresana, J. C. (2004). Productive uses of water at the household level: Evidence from Bushbuckridge, South Africa. In P. Moriarty, J. Butterworth, \& B. Van Koppen (Eds.), Beyond domestic: Case studies on poverty and productive uses of water at the household level (IRC technical papers series 41). Delft: IRC/NRI/IWMI.

Renault, D., Wahaj, R., \& Smits, S. (2013). Multiple uses of water services in large irrigation systems. Auditing and planning modernization (The MASSMUS approach, FAO Irrigation and Drainage Paper 67). Rome: Food and Agriculture Organization of the United Nations.

Republic of South Africa (RSA). (1996). Constitution of the Republic of South Africa (Act No. 108). Statutes of the Republic of South Africa Constitutional Law, Office of the President, Cape Town, South Africa.

Republic of South Africa (RSA). (1997). Water Services Act. Act No. 108 of 1997, Government Gazette No. 18522, Office of the President, Cape Town, South Africa.

Republic of South Africa (RSA). (1998). National Water Act. Act No. 36, Government Gazette Vol. 398, 26 August 1998, Office of the President, Cape Town, South Africa.

South African Human Rights Commission. (2014). Report on the right to access sufficient water and decent sanitation in South Africa. South African Human Rights Commission, Johannesburg. http://www.gov.za/documents/report-right-access-sufficient-water-and-decent-sanitationsouth-africa-2014

Thompson, H. C. M., Stimie, E., Richters, S., \& Perret, S. (2001). Policies, legislation and organizations related to water in South Africa, with special reference to the Olifants River basin (Working paper 18 (South Africa working paper no. 7)). Colombo: International Water Management Institute.

UNICEF., \& World Health Organisation. (2015). Progress on sanitation and drinking water 2015 update and MDG assessment. New York: Joint Monitoring Programme UNICEF/WHO. http://www.wssinfo.org/fileadmin/user_upload/resources/JMP-Update-report-2015_English. pdf

United Nations. (1966). International Covenant on Economic, Social and Cultural Rights (ICESCR) (1966) UN Doc A/6316.

United Nations. (1979). Convention on the Elimination of All Forms of Discrimination against Women (CEDAW) (1979), UN Doc. A/34/46, United Nations, New York, USA.

United Nations. (1990). Convention on the Rights of the Child. General Assembly Resolution 44/25 of 20 November 1989, United Nations, New York, USA.

United Nations. (1993). Vienna Declaration and Programme of Action, UN Doc. A/Conf.157/23 (12 June 1993), United Nations, New York, USA.

United Nations. (2010a). Resolution adopted by the General Assembly. 64/292. The human right to water and sanitation. A/RES/64/292, United Nations, New York, USA.

United Nations. (2010b). Human rights and access to safe drinking water and sanitation, Human Rights Council 6 October 2010, A/HRC/RES/15/9, United Nations, New York, USA.

United Nations Committee on Economic Social and Cultural Rights (CESCR). (2003). General Comment No. 15. The right to water and sanitation (Arts. 11 and 12 of the International Covenant on Economic, Social and Cultural Rights), E/C.12/2002/11, United Nations, New York, USA. http://www2.ohchr.org/english/issues/water/docs/CESCR_GC_15.pdf

Van Koppen, B., \& Schreiner, B. (2015). Gender-equality in statutory water law: The case of priority general authorisations in South Africa. In A. Hellum, M. Kameri, \& B. Van Koppen (Eds.), Water is life: Women's human rights in national and local water governance in Southern and Eastern Africa. Harare: Weaver Press.

Van Koppen, B., Smits, S., Penning De Vries, F., Mikhail, M., \& Boelee, E. (2009). Climbing the water ladder: Multiple-use water services for poverty reduction (Technical report 52). Delft: IRC International Water and Sanitation Centre, International Water Management Institute and CPWF. www.musgroup.net

Van Koppen, B., Smits, S., Rumbaitis del Rio, C., \& Thomas, J. (2014a). Upscaling multiple use water services: Accountability in the water sector. London/The Hague: Practical Action/ IWMI/WLE - International Water and Sanitation Centre IRC - Rockefeller Foundation. 
Van Koppen, B., Van der Zaag, P., Manzungu, E., \& Tapela, B. (2014b). Roman water law in rural Africa: Finishing the unfinished business of colonial dispossession. Water International, 39(1): 49-62. http://dx.doi.org/10.1080/02508060.2013.863636

Verma, S., Kurian, B., Malik, R. P. S., Shah, T., \& Van Koppen, B. (2011). Multiple use water services in India: Scoping study. India: International Water Management Institute, IRC International Water and Sanitation Centre and Rockefeller Foundation.

Water Governance Facility (WGF). (2012). Human rights-based approaches and managing water resources: Exploring the potential for enhancing development outcomes (WGF report no 1). Stockholm: Stockholm International Water Institute.

WaterLex. (2014). National human rights institutions and water governance: Compilation of good practices. Geneva: WaterLex.

Open Access This chapter is distributed under the terms of the Creative Commons AttributionNoncommercial 2.5 License (http://creativecommons.org/licenses/by-nc/2.5/) which permits any noncommercial use, distribution, and reproduction in any medium, provided the original author(s) and source are credited.

The images or other third party material in this chapter are included in the work's Creative Commons license, unless indicated otherwise in the credit line; if such material is not included in the work's Creative Commons license and the respective action is not permitted by statutory regulation, users will need to obtain permission from the license holder to duplicate, adapt or reproduce the material. 